\title{
ANALISIS KINERJA PT. BANK NAGARI MENGGUNAKAN CAMEL
}

\author{
Warzukni, Yosep Eka Putra \\ Akademi Keuangan dan Perbankan "Pembangunan" Padang \\ warzuqni244@gmail.com
}

\begin{abstract}
The purpose of this study was to determine how the Bank's Soundness at PT. Bank Nagari. The research method used is the CAMEL method that manages qualitative and quantitative data. The type of data used is secondary data obtained from financial reports from the Nagari Bank annual report in the 2017-2019 period. The results of this study indicate that the CAR level is in a healthy position. KAP level is in a healthy position, NPM level is in an unhealthy position, Level. ROA and BOPO are in a healthy position, and LDR is in a healthy position.
\end{abstract}

Keyword: Bank, CAMEL

\section{PENDAHULUAN}

Penilaian terhadap kinerja keuangan perusahaan penting dilakukan sebagai sarana atau indikator dalam rangka memperbaiki kegiatan operasional perusahaan sehingga diharapkan perusahaan dapat mengalami pertumbuhan keuangan yang lebih baik dan juga dapat bersaing dengan perusahaan lain (Sipahelut et al., 2018). Cara mengetahui baik atau buruknya kinerja keuangan dalam perusahaan dapat diketahui dengan cara menganalisis hubungan berbagai pos dalam laporan keuangan (Farida Efriyanti, 2019). Kinerja keuangan disebut sebuah analisis yang dilakukan untuk melihat sejauh mana perusahaan menggunakan aturan-aturan pelaksanaan keuangan secara baik dan benar. Membuat suatu laporan keuangan yang telah memenuhi standar dan ketentuan dalam SAK (Standar Akuntansi Keuangan) (Fahmi, 2011).

Laporan keuangan ialah catatan informasi keuangan perusahaan pada periode akuntansi yang digunakan untuk menggambarkan suatu kinerja perusahaan (Kaunang, 2015). Dalam praktiknya apabila laporan keuangan dibuat dan disusun oleh perusahaan tidak sesuai dengan aturan atau standar yang berlaku. Maka agar sebuah laporan keuangan bisa menjadi lebih berarti dan berharga, kemudian juga dapat dipahami dan dimengerti oleh berbagai pihak, maka perlu dilakukan analisis laporan keuangan (Kaligis, 2013). Analisis laporan keuangan sebagai penilaian kinerja keuangan perusahaan yang berfungsi sebagai alat bantu manajemen dalam pengambilan keputusan untuk membuat kebijakan yang tepat dan strategis bagi kelancaran operasional perusahaan. Analisis laporan keuangan bertujuan untuk melihat sehat atau tidak sehat keuangan bank. 
Untuk mengetahui bagaimana tingkat kesehatan bank dapat dinilai dari beberapa indikator. Salah satu indikator utama yang dijadikan dasar penilaian adalah laporan keuangan bank yang bersangkutan. (Spica \& Herdinigtyas, 2005). Terdapat beberapa pihak yang sangat membutuhkan hasil penilaian tingkat kesehatan bank yaitu : pengelolaan bank (Dewan Komisaris, Dewan Direksi, Pemilik), masyarakat pengguna jasa bank, Bank Indonesia (selaku Pembina dan pengawas Bank), Counterparty Bank (adanya hubungan koresponden). Penilaian kesehatan bank oleh bank sentral dengan melakukan penilaian terhadap aspekaspek yang telah ditetapkan. Adapun aspek-aspek yang harus dipenuhi meliputi Capital (modal), Asset (aktiva), Management (manajemen), Earning (rentabilitas), Liquidity (likuditas) yang diangkat menjadi CAMEL (Kevin et al., 2011). Bank yang ingin diketahui kesehatannya dalam penelitian ini adalah PT. Bank Nagari.

PT. Bank Nagari terhitung semenjak dibukanya keran ekonomi yaitu pada

Alat ukur yang digunakan untuk menilai kinerja keuangan dalam penelitian ini adalah metode rasio keuangan CAMEL, yaitu permodalan (Capital), kualitas aset (Asset quality), manajemen (Management), rentabilitas (Earning), likuiditas (Liquidity) selanjutnya akan disingkat dengan CAMEL. Rasio CAMEL adalah indikator untuk mengetahui kemampuan yang menghasilkan laba tahun fiskal berikutnya atau dapat digunakan sebagai indikator untuk mengetahui kesehatan suatu perbankan. Ini dilakukan dengan menggunakan rasio CAMEL sebagai variabel bebas (independent variabel) dan Laba tahun fiskal berikutnya sebagai variabel terikat (dependent variabel) kriteria rasio CAMEL:

a. Capital (modal)

\begin{tabular}{|c|c|}
\hline Kriteria & Nilai \\
\hline CAR $>8 \%$ & Sehat \\
\hline $6,5 \%$ CAR $<7,9 \%$ & Kurang Sehat \\
\hline CAR $<6,5 \%$ & Tidak Sehat \\
\hline
\end{tabular}

Sumber: Kasmir (2008)

b. Asset quality (kualitas aktiva)

\begin{tabular}{|c|c|}
\hline Kriteria & Nilai \\
\hline$>81,0 \%-100 \%$ & Sehat \\
\hline $66,0 \%-<81,0 \%$ & Cukup sehat \\
\hline $51,0 \%-<66,0 \%$ & Kurang sehat \\
\hline$<51,0 \%$ & Tidak sehat \\
\hline
\end{tabular}

Sumber: Kasmir (2008)

c. Management (manajemen)

\begin{tabular}{|c|c|}
\hline Kriteria & Nilai \\
\hline NPM $\geq 8 \%$ & Sehat \\
\hline $7,99 \% \leq \mathrm{NPM}<8 \%$ & Cukup sehat \\
\hline $6,5 \% \leq \mathrm{NPM}<7,99 \%$ & Kurang sehat \\
\hline$\leq 6,5 \%$ & Tidak sehat \\
\hline
\end{tabular}

Sumber: Kasmir (2008) 
d. Earning (pendapatan)

ROA:

\begin{tabular}{|c|c|}
\hline Kriteria & Nilai \\
\hline$>1,22 \%$ & Sehat \\
\hline $0,99 \%-1,21 \%$ & Cukup sehat \\
\hline $0,77 \%-0,98 \%$ & Kurang sehat \\
\hline$<0,76 \%$ & Tidak sehat \\
\hline
\end{tabular}

Sumber: Kasmir (2008)

BOPO:

\begin{tabular}{|c|c|}
\hline Kriteria & Nilai \\
\hline$<93,52 \%$ & Sangat baik \\
\hline $93,52 \%-94,73 \%$ & Baik \\
\hline $94,73 \%-95,92 \%$ & Cukup baik \\
\hline$>95,92 \%$ & Kurang baik \\
\hline
\end{tabular}

Sumber: Kasmir (2008)

e. Liquidity (likuiditas)

\begin{tabular}{|c|c|}
\hline Kriteria & Nilai \\
\hline$<94,75 \%$ & Sehat \\
\hline $94,75 \%-98,75 \%$ & Cukup sehat \\
\hline $98,75 \%-102,25 \%$ & Kurang sehat \\
\hline$>102,25 \%$ & Tidak sehat \\
\hline
\end{tabular}

\section{Sumber : Kasmir (2008)}

Dari tabel kriteria dan nilai di atas, akan menjadi acuan dalam menganalisis kinerja keuangan pada PT. Bank Nagari untuk mengetahui kesehatan keuangan bank. Berikut ini laporan keuangan PT. Bank Nagari tahun 2017-2019.

Tabel 1

Laporan keuangan PT. Bank Nagari tahun 2017-2019

\begin{tabular}{|l|l|l|l|}
\hline Keterangan & $\mathbf{2 0 1 7}$ & $\mathbf{2 0 1 8}$ & $\mathbf{2 0 1 9}$ \\
\hline Modal & 2.638 .687 .060 .316 & 2.900 .346 .936 .365 & 3.149 .765 .615 .122 \\
\hline ATMR & 15.013 .788 .515 .926 & 15.942 .648 .869 .123 & 16.481 .090 .981 .257 \\
\hline $\begin{array}{l}\text { Aktiva } \\
\begin{array}{l}\text { Produktif yang } \\
\text { dilikasifikasika } \\
\text { n }\end{array}\end{array}$ & 296.693 .666 .505 & 241.608 .164 .662 & 285.553 .261 .024 \\
\hline $\begin{array}{l}\text { Total Aktiva } \\
\text { Produktif }\end{array}$ & 16.361 .765 .620 .144 & 16.551 .363 .730 .819 & 18.228 .295 .862 .935 \\
\hline Laba Bersih & 301.124 .236 .482 & 344.323 .016 .230 & 377.106 .551 .735 \\
\hline $\begin{array}{l}\text { Pendapatan } \\
\text { Opersional }\end{array}$ & 1.361 .069 .726 .767 & 1.568 .316 .770 .854 & 1.598 .333 .426 .948 \\
\hline Total aktiva & 21.371 .463 .635 .573 & 23.190 .691 .424 .930 & 24.433 .595 .767 .423 \\
\hline Kredit yang & 14.706 .583 .341 .163 & 15.896 .871 .467 .104 & 17.110 .009 .321 .080 \\
\hline
\end{tabular}




\begin{tabular}{|l|l|l|l|}
\hline Diberikan & & & \\
\hline $\begin{array}{l}\text { Dana Pihak } \\
\text { Ketiga +Modal }\end{array}$ & 17.617 .910 .248 .669 & 19.208 .756 .803 .372 & 21.132 .566 .070 .358 \\
\hline $\begin{array}{l}\text { Beban } \\
\text { Operasional }\end{array}$ & 877.425 .892 .964 & 977.287 .696 .839 & 1.029 .766 .559 .680 \\
\hline $\begin{array}{l}\text { Pendapatan } \\
\text { Operasional }\end{array}$ & 1.361 .069 .726 .767 & 1.568 .316 .770 .854 & 1.598 .333 .426 .948 \\
\hline
\end{tabular}

Sumber: Annual Report Bank Nagari

Dari permasalahan yang telah dipaparkan di atas, maka penulis akan mengungkapkan bagaimana Analisis Kinerja PT. Bank Nagari menggunakan CAMEL.

Berdasarkan uraian di atas, penulis tertarik untuk menelitinya dan menuangkan dalam Tugas Akhir dengan judul "Analisis Kinerja PT. Bank Nagari menggunakan CAMEL".

METODE PENELITIAN.

Dalam pengumpulan data dan bahan untuk melakukan penelitian ini, digunakan metode-metode sebagai berikut:

\section{Metode Pengumpulan Data}

a. Dokumentasi

Pengumpulan data dilakukan dengan cara wawancara langsung dengan responden sesuai dengan tujuan penelitian.

b. Studi Kepustakaan (Library Research)

Studi pustaka dengan cara mempelajari dan mengambil data dari literatur dan sumber-sumber lainnya yang dianggap dapat memberikan informasi mengenai penelitian ini.

\section{Metode Analis Data}

Adapun metode data yang digunakan adalah metode kualitatif dan kuantitatif. Dimana metode kualitatif merupakan metode yang dilakukan untuk mendapatkan informasi terkait melalui wawancara terhadap PT. Bank Nagari dan menggunakan metode kuantitatif, yaitu metode yang dapat digunakan untuk melakukan perhitungan data dalam bentuk tabel. 
HASIL DAN PEMBAHASAN

1. Capital (Modal)

Modal

ATMR

CAR : $\quad$ x $100 \%$

\begin{tabular}{|c|c|}
\hline Kriteria & Nilai \\
\hline CAR $>8 \%$ & Sehat \\
\hline $6,5 \%$ CAR $<7,9 \%$ & Kurang Sehat \\
\hline CAR $<6,5 \%$ & Tidak Sehat \\
\hline
\end{tabular}

Sumber: Kasmir (2008)

sebagai berikut:

CAR dari tahun 2017 sampai dengan tahun 2019 perhitungannya

Tabel 1

Perhitungan Capital (Modal)

Tahun 2017-2019

\begin{tabular}{|c|c|c|c|}
\hline Tahun & Modal (1) & ATMR (2) & $\begin{array}{c}\text { CAR } \\
(\mathbf{1} * \mathbf{2}) * \mathbf{1 0 0}\end{array}$ \\
\hline 2017 & 2.638 .687 .060 .316 & 15.013 .788 .515 .926 & 17,58 \\
\hline 2018 & 2.900 .346 .936 .365 & 15.942 .648 .869 .123 & 18,19 \\
\hline 2019 & 3.149 .765 .615 .122 & 16.481 .090 .981 .257 & 19,11 \\
\hline
\end{tabular}

Sumber : Data diolah

Dari tabel diatas dapat dilihat bahwa nilai Capital Adequacy Ratio (CAR)

PT. Bank Nagari untuk tahun 2017 sebesar 17,58\%, dengan modal sebasar Rp.2.638.687.060.316 dan Aktiva Tertimbang Menurut Resiko (ATMR) sebesar Rp.15.013.788.515.926, artinya setiap Rp.100 nilai Aktiva Tertimbang Menurut Resiko (ATMR), maka nilai modal sebanding dengan Rp.17,58. Pada tahun 2018 nilai mengalami kenaikan menjadi sebasat $18,19 \%$, dengan modal sebasar Rp,2.900.346.936.365 dan nilai ATMR sebesar Rp. 15.942.648.869.123, artinya setiap Rp.100 nilai modal sebanding dengan nilai Rp.18,19 ATMR. Terjadinya peningkatan nilai CAR disebabkan oleh nilai ATMR yang juga mengalami peningkatan. Pada tahun 2019 nilai CAR kembali mengalami peningkatan dari tahun sebelumnya menjadi sebasar 19,11, dengan nilai modal sebasar Rp.3.149.765.615.122 dan nilai ATMR sebesar Rp.16.481.090.981.257, artinya setiap Rp.100 modal, sebanding dengan nilai 19,11 ATMR.

Dari penjelesan diatas, dapat dilihat bahwa PT. Bank Nagari pada tahun 2017 sampai 2019 nilai kredit faktor permodalan nilai bobotnya sebesar 100, yang mana besar dari ketentuan Bank Indonesia maka dapat dikatakan PT. Bank Nagari dalam keadaan SEHAT. Maka dapat dijelaskan bahwa dalam 
kurun waktu tahun 2017 sampai 2019 PT. Bank Nagari memiliki kecukupan modal yang ditunjang oleh aktiva tertimbang menurut risko.

\section{Asset quality (Kualitas aktiva)}

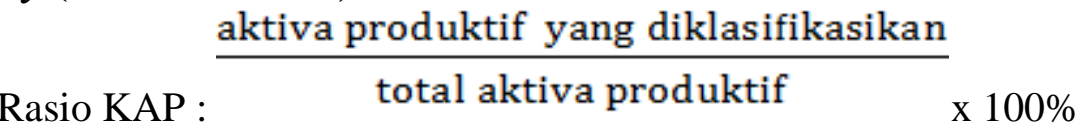

\begin{tabular}{|c|c|}
\hline Kriteria & Nilai \\
\hline$>81,0 \%-100 \%$ & Sehat \\
\hline $66,0 \%-<81,0 \%$ & Cukup sehat \\
\hline $51,0 \%-<66,0 \%$ & Kurang sehat \\
\hline$<51,0 \%$ & Tidak sehat \\
\hline
\end{tabular}

Sumber: Kasmir (2008)

KAP dari tahun 2017 sampai dengan tahun 2019 perhitungannya sebagai berikut:

Tabel 2

Perhitungan Assets Quality (Kualitas Aset) Tahun 2017-2019

\begin{tabular}{|c|c|c|c|}
\hline Tahun & APYD (1) & Aktiva Produktif (2) & $\begin{array}{c}\text { KAP } \\
(\mathbf{1} * \mathbf{2}) * \mathbf{1 0 0}\end{array}$ \\
\hline 2017 & 296.693 .666 .505 & 16.361 .765 .620 .144 & 1,81 \\
\hline 2018 & 241.608 .164 .662 & 16.551 .363 .730 .819 & 1,46 \\
\hline 2019 & 285.553 .261 .024 & 18.228 .295 .862 .935 & 1,57 \\
\hline
\end{tabular}

Sumber : Data diolah

Aktiva produktif yang diklasifikasikan merupakan cadangan aktiva yang dimiliki oleh PT. Bank Nagari yang dinilai dari kredit kurang lancar sebesar 50\%, kredit diragukan $70 \%$ dan kredit macet sebasar 100\%. Pada tahun 2017 nilai KAP sebesar 1,81\%, nilai Aktiva Produktif Yang Diklasifikasikan sebesar Rp.296.693.666.505 dan Aktiva Produktiv sebesar Rp.16.361.765.620.144, artinya setiap Rp. 100 aktiva produktiv sebanding dengan Rp,1,81 aktiva produktif yang diklasifkasikan, pada tahun 2018 nilai KAP mengalami penurunan menjadi sebesar $1,46 \%$, dengan nilai aktiva produktif yang diklasifikasikan sebesar Rp.241.608.164.662 dan aktiva produktif sebesar Rp.16.551.363.730.819, artinya setiap Rp. 100 aktiva produktif sebanding dengan 1,46 aktiva produktif yang diklasifikasikan, terjadinya penurunan terhadap nilai KAP disebabkan oleh terjadinya penurunan kredit macet, karena PT. Bank Nagari telah melakukan penagihan tethadap kredit macet, sehingga aset yang beresiko dapat dikurangi.

Dari penjelesan diatas, dapat dilihat bahwa PT. Bank Nagari pada tahun 2017 sampai 2019 nilai kredit faktor kualitas aset nilai bobotnya sebesar 100, maka dapat dikatakan PT. Bank Nagari dalam keadaan SEHAT. Maka 
dapat dijelaskan bahwa dalam kurun waktu tahun 2017 sampai 2019 PT. Bank Nagari memiliki kualitas aset yang baik.

\section{Management (Manajemen)}

laba bersih

Rasio NPM : $\overline{\text { pendapatan operasional }} \times 100 \%$

\begin{tabular}{|c|c|}
\hline Kriteria & Nilai \\
\hline $\mathrm{NPM} \geq 8 \%$ & Sehat \\
\hline $7,99 \% \leq \mathrm{NPM}<8 \%$ & Cukup sehat \\
\hline $6,5 \% \leq \mathrm{NPM}<7,99 \%$ & Kurang sehat \\
\hline$\leq 6,5 \%$ & Tidak sehat \\
\hline
\end{tabular}

Sumber: Kasmir (2008)

NPM dari tahun 2017 sampai dengan tahun 2019 perhitungannya sebagai berikut:

\section{Tabel 3}

\section{Perhitungan Management (Manajemen)}

Tahun 2017-2019

\begin{tabular}{|c|c|c|c|}
\hline Tahun & Laba Bersih (1) & $\begin{array}{c}\text { Pendapatan } \\
\text { Operasional (2) }\end{array}$ & NPM (1*2)*100 \\
\hline 2017 & 301.124 .236 .482 & 1.361 .069 .726 .767 & 22,12 \\
\hline 2018 & 344.323 .016 .230 & 1.568 .316 .770 .854 & 21,95 \\
\hline 2019 & 377.106 .551 .735 & 1.598 .333 .426 .948 & 23,59 \\
\hline
\end{tabular}

Sumber : Data diolah

Untuk mengukur faktor manajemen digunakan rasio Net Profir Margin (NPM), yang mana diukur dari laba bersih dibagi dengan pendapatan operasional. Pada tahun 2017 nilai Net Profir Margin (NPM) PT. Bank Nagari sebesar 22,12\%, dengan laba bersih sebasar Rp.301.124.236.482 dan pendapatan operasional sebesar Rp. 1.361.069.726.767, artinya Rp.100 pendapatan operasional akan menghasilakan Rp.22,12 laba bersih. Pada tahun 2018 nilai Net Profir Margin (NPM) PT. Bank Nagari mengalami penurunan menjadi sebesar 21,59\%, dengan nilai laba bersih sebesar Rp. 344.323.016.230 dan pendapatan operasional sebesar Rp. 1.568.316.770.854, terjadinya penurunan nilai NPM disebabkan oleh tingginya beban operasional perusahaan, sehingga laba bersih yang dihasilkan tidak sebanding dengan pendapatan yang diperoleh. Pada tahun 2019 Net Profir Margin (NPM) PT. Bank Nagari mengalami kenaikan menjadi sebesar 23,59, dengan laba bersih sebesar Rp. 377.106.551.735 dan pendapatan operasional sebesar Rp. 1.598.333.426.948, artinya setiap kenaikan Rp,100 laba operasional akan menghasilkan laba bersih Rp.23,59. 
Dari penjelasan diatas, dapat dilihat bahwa PT. Bank Nagari pada tahun 2017 sampai 2019 nilai kredit manajemen nilai rasionya pada tahun 2017 sebesar 21,95, tahun 2018 sebesar 21,95 dan tahun 2019 sebesar 23,595, nilai tersebut berada $<51 \%$, maka dapat dikatakan PT. Bank Nagari dalam keadaan TIDAK SEHAT. Maka dapat dijelaskan bahwa dalam kurun waktu tahun 2017 sampai 2019 PT. Bank Nagari tidak dapat memperoleh laba dengan maksimal dengan memanfaatkan pendapatan operasionalnya, hal ini disebabkan tingginya beban operasional, sehingga laba yang diperoleh cenderung kecil.

\section{Earning (Pendapatan)}

\section{a. ROA}

\begin{tabular}{|c|c|}
\hline \multicolumn{2}{|c|}{$\mathrm{ROA}=:^{\frac{\text { laba bersih }}{\text { Total aktiva }}} \times 100 \%$} \\
\hline Kriteria & Nilai \\
\hline$>1,22 \%$ & Sehat \\
\hline $0,99 \%-1,21 \%$ & Cukup sehat \\
\hline $0,77-0,98 \%$ & Kurang sehat \\
\hline$<0,76 \%$ & Tidak sehat \\
\hline
\end{tabular}

Sumber: Kasmir (2008)

ROA dari tahun 2017 sampai dengan tahun 2019 perhitungannya sebagai berikut:

Tabel 4

Perhitungan Return on Assest (ROA)

Tahun 2017-2019

\begin{tabular}{|c|c|c|c|}
\hline Tahun & Laba Bersih (1) & Total Aktiva (2) & $\begin{array}{c}\text { ROA } \\
(\mathbf{1} * \mathbf{2}) * \mathbf{1 0 0}\end{array}$ \\
\hline 2017 & 301.124 .236 .482 & 21.371 .463 .635 .573 & 1,41 \\
\hline 2018 & 344.323 .016 .230 & 23.190 .691 .424 .930 & 1,48 \\
\hline 2019 & 377.106 .551 .735 & 24.433 .595 .767 .423 & 1,54 \\
\hline
\end{tabular}

Sumber : Data diolah

Dari analisis rasio terhadap laba yang diukur dengan Return on Asset (ROA) PT. Bank Pembangunan Daerah Sumatera Barat pada tahun 2017 sebesar 1,41\%, pada tahun 2018 sebesar 1,48\% lalu pada tahun 2019 sebesar 1,54\%. Berdasarkan hasil perhitungan tersebut, PT. Bank Nagari mampu menjaga ROA tetap berada diantara $1,25 \% \quad-1,5 \%$ sehingga berdasarkan kriteria penilaian ROA PT. Bank Nagari dapat dikategorikan dalam kelompok SEHAT. Dengan tingginya rasio ROA ini menunjukkan bahwa PT. Bank Nagari mampu dengan baik dalam mengelola asset bank yang dimiliki untuk menghasilkan laba. Dari 3 tahun periode nilai bank yang terlihat bagus pada tahun 2019 1,54\% karena laba bersih dan total aktiva naik. Karena 
kemampuan bank dalam menghasilkan laba sangat bagus dapat dilihat dari nilai total aktiva dari tahun ke tahun meningkat.

Dari penjelesan diatas, dapat dilihat bahwa PT. Bank Nagari pada tahun 2017 sampai 2019 nilai kredit faktor laba nilai bobotnya pada tahun 2017 sebesar 94, tahun 2018 sebesar 99 dan tahun 2019 sebesar 103, maka dapat dikatakan PT. Bank Nagari dalam keadaan SEHAT. Maka dapat dijelaskan bahwa dalam kurun waktu tahun 2017 sampai 2019 PT. Bank Nagari memiliki return on assets yang cukup baik.

\section{beban operasional \\ a. $\mathrm{BOPO}=\overline{\text { pendapatan operasional }} \times 100 \%$}

\begin{tabular}{|c|c|}
\hline Kriteria & Nilai \\
\hline$<93,52 \%$ & Sehat \\
\hline $93,52 \%-94,73 \%$ & Cukup Sehat \\
\hline $94,73-95,92 \%$ & Kurang Sehat \\
\hline$>95,92 \%$ & Tidak Sehat \\
\hline
\end{tabular}

Sumber: Kasmir (2008)

BOPO dari tahun 2017 sampai dengan tahun 2019 perhitungannya sebagai berikut:

Tabel 5

Perhitungan BOPO

Tahun 2017-2019

\begin{tabular}{|c|c|c|c|}
\hline Tahun & $\begin{array}{c}\text { Beban Operasional } \\
(\mathbf{1})\end{array}$ & $\begin{array}{c}\text { Pendapatan } \\
\text { Operasional (2) }\end{array}$ & $\begin{array}{c}\text { BOPO } \\
(\mathbf{1} * \mathbf{2}) * \mathbf{1 0 0}\end{array}$ \\
\hline 2017 & 877.425 .892 .964 & 1.361 .069 .726 .767 & 64,47 \\
\hline 2018 & 977.287 .696 .839 & 1.568 .316 .770 .854 & 62,31 \\
\hline 2019 & 1.029 .766 .559 .680 & 1.598 .333 .426 .948 & 64,43 \\
\hline
\end{tabular}

Sumber : Data diolah

Dari laporan PT. Bank Nagari BOPO tahun 2017 64,47\%, pada tahun 2018 BOPO sebesar 62,31\% dan pada tahun 2019 BOPO sebesar 64,43\%. Berdasarkan hasil perhitungan tersebut, PT. Bank Nagari mampu menjaga BOPO tetap berada di bawah 94\% sehingga berdasarkan kriteria penilaian BOPO PT. Bank Nagari dapat dikategorikan dalam kelompok SEHAT. Dengan demikian kecilnya rasio BOPO maka semakin efisien PT. Bank Nagari dalam melakukan kegiatan operasionalnya karena biaya yang dikeluarkan lebih kecil dibandingkan pendapatan yang diterima. Dari 3 tahun periode BOPO yang hasilnya bagus pada tahun 2018 sebesar 62,31\%. Karena pendapatan operasionalnya lebih besar sehingga dapat menutupi beban 
operasionalnya. Semakin tinggi nilai rasio BOPO maka semakin tidak efisien biaya operasional bank.

Dari tabel diatas diketahui bahwa selama kurun waktu 2017-2019, PT. Bank Nagari dapat mempertahankan nilai kredit rasio BOPO-nya pada nilai maksimal, yaitu 100, untuk tetap dikategorikan bank yang SEHAT. Ini berarti bahwa dalam kurun waktu tersebut, manajemen PT. Bank Nagari memiliki kemampuan yang baik dalam mengendalikan biaya operasional yang harus dikeluarkan terhadap pendapatan operasionalnya yang diperolehnya.

\section{Liquidity (Likuiditas)}

$$
\text { LDR }=\frac{\text { Total utang }}{\text { Total deposit+ ekuitas }} \times 100 \%
$$

\begin{tabular}{|c|c|}
\hline Kriteria & Nilai \\
\hline$<94,75 \%$ & Sehat \\
\hline $94,75 \%-98,75 \%$ & Cukup sehat \\
\hline $98,75 \%-102,25 \%$ & Kurang sehat \\
\hline$>102,25 \%$ & Tidak sehat \\
\hline
\end{tabular}

Sumbar: Kasmir (2008)

LDR dari tahun 2017 sampai dengan tahun 2019 perhitungannya sebagai berikut:

\section{Tabel 6}

\section{Perhitungan Liquidity (LDR)}

Tahun 2017-2019

\begin{tabular}{|c|c|c|c|}
\hline Tahun & $\begin{array}{c}\text { Kredit yang } \\
\text { Diberikan (1) }\end{array}$ & $\begin{array}{c}\text { Dana Pihak Ketiga } \\
\text { +Modal }(\mathbf{2})\end{array}$ & $\begin{array}{c}\text { LDR } \\
(\mathbf{1} * \mathbf{2}) * \mathbf{1 0 0}\end{array}$ \\
\hline 2017 & 14.706 .583 .341 .163 & 17.617 .910 .248 .669 & 83,48 \\
\hline 2018 & 15.896 .871 .467 .104 & 19.208 .756 .803 .372 & 82,76 \\
\hline 2019 & 17.110 .009 .321 .080 & 21.132 .566 .070 .358 & 80,97 \\
\hline
\end{tabular}

Sumber : Data diolah

Berdasarkan laporan keuangan PT. Bank Nagari pada tahun 2017 adalah 83,48\%, pada tahun 2018 sebesar 82,76\% dan pada tahun 2019 adalah sebesar $80,97 \%$. Berdasarkan hasil perhitungan tersebut, PT. Bank Nagari mampu menjaga LDR tetap berada di bawah 94,75\% sehingga berdasarkan kriteria penilaian LDR PT. Bank Nagari dapat dikategorikan dalam kelompok SEHAT. Dari 3 tahun periode LDR yang nilainya bagus pada tahun 2019 sebesar $80,97 \%$. Karena kemampuan bank dalam memperoleh total deposit + ekuitas sangat bagus seimbang dengan total utang yang diberikan, jika nilai LDR semakin tinggi maka tingkat likuiditas bank yang semakin rendah, karena 
jumlah utang semakin besar sehingga jumlah dana yang diperlukan untuk membayar utang tersebut semakin besar.

Dari tabel diatas diketahui bahwa selama kurun waktu 2017-2019, PT.

Bank Nagari dapat mempertahankan nilai kredit rasio LDR-nya pada nilai maksimal, yaitu 100, untuk tetap dikategorikan bank yang SEHAT. Ini berarti bahwa dalam kurun waktu tersebut, manajemen PT. Bank Nagari memiliki kemampuan yang baik dalam mengendalikan biaya operasional yang harus dikeluarkan terhadap pendapatan operasionalnya yang diperolehnya.

\section{Analisis Tingkat Kesehatan PT. Bank Nagari}

Setelah menghitung dan mengetahui rasio dari laporan keuangan bank dan nilai kredit dari masing-masing rasio, maka tingkat kesehatan PT. Bank Nagari sudah dapat diketahui, yaitu dengan menggunakan metode CAMEL sebagai beriku:

Tabel 7

Tingkat Kesehatan Bank dengan Metode CAMEL

\begin{tabular}{|c|c|}
\hline Nilai Kredit CAMEL & Predikat \\
\hline $81 \%-100 \%$ & Sehat \\
\hline $66 \%-<81 \%$ & Cukup Sehat \\
\hline $51 \%-<66$ & Kurang Sehat \\
\hline $0-<51 \%$ & Tidak Sehat \\
\hline
\end{tabular}

1. Tahun 2017

Berikut ini kinerja keuangan untuk menilai tingkat kesehatan PT. Bank Nagari pada tahun 2017 yang diukur dengan metode CAMEL dan nilai kredit sebagai berikut:

Tabel 8

Tingkat Kesehatan Bank

Tahun 2017

\begin{tabular}{|c|c|c|c|c|c|}
\hline Tahun & $\begin{array}{c}\text { Faktor } \\
\text { CAMEL }\end{array}$ & $\begin{array}{c}\text { Nilai Rasio } \\
(\%)\end{array}$ & $\begin{array}{c}\text { Nilai } \\
\text { Kredit }\end{array}$ & $\begin{array}{c}\text { Bobot } \\
(\%)\end{array}$ & $\begin{array}{c}\text { Nilai CAMEL } \\
(\%)\end{array}$ \\
\hline \multirow{8}{*}{2017} & CAR & 17,58 & 100 & 25 & 25 \\
\hline & KAP & 1,81 & 100 & 30 & 30 \\
\hline & NPM & 22,12 & 22,12 & 25 & 5,53 \\
\hline & ROA & 1,41 & 94 & 5 & 4,7 \\
\hline & BOPO & 64,47 & 100 & 5 & 5 \\
\hline & LDR & 83,48 & 100 & 10 & 10 \\
\hline & \multicolumn{4}{|c|}{ Jumlah Nilai Camel } & 80,23 \\
\hline & \multicolumn{4}{|c|}{ Kesehatan Bank } & SEHAT \\
\hline
\end{tabular}

Sumber : Data diolah 
Tahun 2017 PT. Bank Nagari memperoleh CAMEL sebesar 80,23\% nilai tersebut berada diantara 81\%-100\%, maka dapat kategori (CUKUP SEHAT) hal ini diperoleh dari rasio CAR sebesar 17,58\% yaitu mampu mencukupi modal dalam menutup resiko dari aktiva teetimbang menurut resiko, rasio KAP sebesar $1,81 \%$ yaitu mampu menekan masalah aktiva produktifnya, rasio NPM sebesar $22,12 \%$ yaitu mampu menghasilkan laba bersih dari laba operasionalnya, rasio ROA sebesar $1,41 \%$ yaitu mampu mengelola terhadap nilai total aset untuk menghasilkan laba sebelum pajak, rasio BOPO sebesar $64,47 \%$ yaitu mampu mengefisiensi setiap beban operasional terhadap pendapatan operasionalnya, dan rasio LDR sebesar $83,48 \%$ yaitu mampu menunjukkan tingkat kemampuan bank dalam menyalurkan dana yang berasal dari dana pihak ketiga.

\section{Tahun 2018}

Berikut ini kinerja keuangan untuk menilai tingkat kesehatan PT. Bank Nagari pada tahun 2018 yang diukur dengan metode CAMEL dan nilai kredit sebagai berikut:

\section{Tabel 9}

Tingkat Kesehatan Bank Tahun 2018

\begin{tabular}{|c|l|c|c|c|c|}
\hline \multirow{3}{*}{ Tahun } & \multicolumn{1}{|c|}{$\begin{array}{c}\text { Faktor } \\
\text { CAMEL }\end{array}$} & $\begin{array}{c}\text { Nilai Rasio } \\
(\mathbf{\%})\end{array}$ & $\begin{array}{c}\text { Nilai } \\
\text { Kredit }\end{array}$ & $\begin{array}{c}\text { Bobot } \\
(\mathbf{\%})\end{array}$ & $\begin{array}{c}\text { Nilai } \\
\text { CAMEL } \\
(\boldsymbol{\%})\end{array}$ \\
\hline \multirow{6}{*}{2018} & CAR & 18,19 & 100 & 25 & 25 \\
\cline { 2 - 6 } & KAP & 1,46 & 100 & 30 & 30 \\
\cline { 2 - 6 } & NPM & 21,95 & 21,95 & 25 & 5,5 \\
\cline { 2 - 6 } & ROA & 1,48 & 99 & 5 & 4,95 \\
\cline { 2 - 6 } & BOPO & 62,31 & 100 & 5 & 5 \\
\cline { 2 - 6 } & LDR & 82,76 & 100 & 10 & 10 \\
\cline { 2 - 6 } & \multicolumn{5}{|c|}{ Jumlah Nilai Camel } \\
\cline { 2 - 6 } & \multicolumn{5}{|c|}{ Kesehatan Bank } \\
\hline
\end{tabular}

\section{Sumber : Data diolah}

Tahun 2017 PT. Bank Nagari memperoleh CAMEL sebesar 80,45\% nilai tersebut berada diantara 81\%-100\%, maka dapat kategori (CUKUP SEHAT) hal ini diperoleh dari rasio CAR sebesar $18,19 \%$ naik dari tahun sebelumnya, hal ini menandakan terjadinya kenaikan modal dalam menutup resiko dari aktiva teetimbang menurut resiko, rasio KAP sebesar 1,46\% yaitu mampu menekan masalah aktiva produktifnya, rasio NPM sebesar 21,95\% yaitu mampu menghasilkan laba bersih dari laba operasionalnya, rasio ROA sebesar 1,48\% yaitu mampu mengelola terhadap nilai total aset untuk menghasilkan laba sebelum pajak, rasio BOPO sebesar $62,31 \%$ yaitu mampu mengefisiensi setiap beban operasional terhadap pendapatan operasionalnya, 
dan rasio LDR sebesar $82,76 \%$ yaitu mampu menunjukkan tingkat kemampuan bank dalam menyalurkan dana yang berasal dari dana pihak ketiga.

3. Tahun 2019

Berikut ini kinerja keuangan untuk menilai tingkat kesehatan PT. Bank Nagari pada tahun 2019 yang diukur dengan metode CAMEL dan nilai kredit sebagai berikut:

Tabel 10

Tingkat Kesehatan Bank

Tahun 2019

\begin{tabular}{|c|l|c|c|c|c|}
\hline \multirow{3}{*}{ Tahun } & \multicolumn{1}{|c|}{$\begin{array}{c}\text { Faktor } \\
\text { CAMEL }\end{array}$} & $\begin{array}{c}\text { Nilai Rasio } \\
(\mathbf{\%})\end{array}$ & $\begin{array}{c}\text { Nilai } \\
\text { Kredit }\end{array}$ & $\begin{array}{c}\text { Bobot } \\
(\mathbf{\%})\end{array}$ & $\begin{array}{c}\text { Nilai } \\
\text { CAMEL } \\
(\mathbf{\%})\end{array}$ \\
\hline \multirow{6}{*}{2019} & CAR & 19,11 & 100 & 25 & 25 \\
\cline { 2 - 7 } & KAP & 1,57 & 100 & 30 & 30 \\
\cline { 2 - 6 } & NPM & 23,59 & 23,59 & 25 & 5,9 \\
\cline { 2 - 6 } & ROA & 1,54 & 100 & 5 & 5 \\
\cline { 2 - 6 } & BOPO & 64,43 & 100 & 5 & 5 \\
\cline { 2 - 6 } & LDR & 80,97 & 100 & 10 & 10 \\
\cline { 2 - 6 } & \multicolumn{5}{|c|}{ Jumlah Nilai Camel } \\
\cline { 2 - 6 } & \multicolumn{5}{|c|}{ Kesehatan Bank } \\
\hline
\end{tabular}

Sumber : Data diolah

Tahun 2017 PT. Bank Nagari memperoleh CAMEL sebesar 80,90\% nilai tersebut berada diantara 81\%-100\%, maka dapat kategori (CUKUP SEHAT) hal ini diperoleh dari rasio CAR sebesar 19,11\% naik dari tahun sebelumnya, hal ini menandakan terjadinya kenaikan modal dalam menutup resiko dari aktiva teetimbang menurut resiko, rasio KAP sebesar 1,57\% yaitu mampu menekan masalah aktiva produktifnya, rasio NPM sebesar 23,59\% yaitu mampu menghasilkan laba bersih dari laba operasionalnya, rasio ROA sebesar $1,54 \%$ yaitu mampu mengelola terhadap nilai total aset untuk menghasilkan laba sebelum pajak, rasio BOPO sebesar 64,43\% yaitu mampu mengefisiensi setiap beban operasional terhadap pendapatan operasionalnya, dan rasio LDR sebesar 80,97\% yaitu mampu menunjukkan tingkat kemampuan bank dalam menyalurkan dana yang berasal dari dana pihak ketiga.

\section{UCAPAN TERIMA KASIH}

Penulis mengucapkan terima kasih kepada:

1. Kedua orang tua yang senantiasa merawat dan mndidik serta mncurahkan kasi sayang pada penulis. 
2. Direkur AKBP beserta prodi AKBP serta bapak ibuk dosen yang tela mendidik dan mmberikan ilmu pngetahuan kepada penulis.

3. Pemimpin PT. Bank Nagari yang telah mengizinkan penulis memperoleh informasi

4. Kepada semua piak yang telah membantu dalam membuat tugas akhir.

\section{DAFTAR PUSTAKA}

Abdullah, F., \& Suryanto, L. (2004). Analisis Pengaruh Rasio-Rasio Camel Sebagai Penilaian Tingkat Kesehatan Bank Terhadap Harga Saham Perusahaan Perbankan Yang Terdaftar Di Bursa Efek Jakarta. Analisis Pengaruh RasioRasio Camel Sebagai Penilaian Tingkat Kesehatan Bank Terhadap Harga Saham Perusahaan Perbankan Yang Terdaftar Di Bursa Efek Jakarta, 1(2), 18. https://doi.org/10.14710/jsmo.v1i2.4194

Arifin, I. Z., \& Marlius, D. (2017). Analisis Kinerja Keuangan PT. Pegadaian Cabang Ulak Karang. https://doi.org/10.31227/osf.io/n2peu

Badria, M., \& Marlius, D. (2019). Analisis Rasio Likuiditas Pada PT. Bank Perkreditan Rakyat (BPR) Lengayang. https://doi.org/10.31219/osf.io/esvb7

Dwi, K., Dan, R., Ode, L., Mahasiswa, S., Dosen, D., \& Bisnis, A. (2016). Analisis Laporan Keuangan Dalam Mengukur Kinerja Perusahan Pada Pt. Ricky Kurniawan Kertapersada (Makin Group) Jambi. 2(2), 190-207.

Fitri, H. Y., \& Marlius, D. (2019). Analisis Rasio Likuiditas Pada PT. Bank Perkreditan Rakyat (BPR) Nagari Kasang. https://doi.org/10.31219/osf.io/bcs73

Fahmi, I. (2011). Analisa Laporang Keuangan. In Bandung : Alfabeta.

Farida Efriyanti. (2019) No Title No Title. ANALISIS KINERJA KEUANGAN SEBAGAI DASAR INVESTOR DALAM MENANAMKAN MODAL PADA PT. BUKIT ASAM,TBK, 1, 1-476. https://doi.org/10.1017/CBO9781107415324.004

Hakim, A., \& Wuryanto. (2004). Model Peningkatan Kinerja Karyawan Melalui Peran Komunikasi Dan Motivasi Serta Pengaruhnya Terhadap Kepuasan Kerja. Jurnal Manajemen Bisnis Indonesia, 5(1), 1-18.

Hanafi, Mamduh M; Halim, A. (2012). Analisis Laporan Keuangan, Edisi Keempat. Yogyakarta: UPP STIM YKPN.

Indyarwati, E. V.;, \& Handayani, N. (2017). Pengaruh Rasio CAMEL terhadap Kinerja Keuangan Perbankan Syariah. Jurnal Ilmu Dan Riset Akuntansi, 6(8), 115.

Kaligis, Y. (2013). Analisis Tingkat Kesehatan Bank Dengan Menggunakan Metode Camel Pada Industri Perbankan Bumn Yang Terdaftar Di Bursa Efek Indonesia. Jurnal Riset Ekonomi, Manajemen, Bisnis Dan Akuntansi, 1(3), 263-272.

Kaunang, S. A. (2015). Current Ratio. Analisis Kinerja Keuangan Perushaan Pada PT. Cipta Daya Nusantara Manado, 1(4), 1993-2003. https://doi.org/10.5040/9781472920294.0035

Kevin, J., Jacob, D., Ekonomi, F., Akuntansi, J., Sam, U., \& Manado, R. (2011). bank, CAMEL, kesehatan bank. 1(3), 691-700. 
Maharani, A. dhiah. (2010). Analisi Pengaruh Kepercayaan dan Kepuasan Terhadap Loyalitas Nasbah tabungan Bank Mega semarang. Navigation, 129. https://doi.org/10.1002/j.2161-4296.1970.tb00024.x

Manimpurung, L., Nangoy, S., \& Mangantar, M. (2014). Analisis Kinerja Keuangan Dengan Menggunakan Camel Pada Pt. Bank Rakyat Indonesia (Persero) Tbk. Jurnal Riset Ekonomi, Manajemen, Bisnis Dan Akuntansi, 2(1), 404-410.

Marlius, D., \& Mutia, M. (2020). Analisis Rasio Profitabilitas Pada Pt. Bank Pembangunan Daerah Sumatera Barat Cabang Pembantu Rsup Dr. M. Djamil Padang. https://doi.org/10.31219/osf.io/9nrc7

Mulyadi. (2016). Sistem Akuntasi. Salemba Empat.

Munawir. (2010). Analisa Laporan Keuangan Edisi 4. In Jakarta: Salemba Empat.

Murdiati, S., \& Purwanto, M. T. (2015). Analisis Kinerja Dengan Menggunakan Pendekatan Rasio Camel. Jurnal Dinamika Manajemen, 5(1), 12. https://doi.org/10.15294/jdm.v5i1.3648

Mustika, S., \& Marlius, D. (2019). Analisa Tingkat Kesehatan Keuangan PT. Bank Perkreditan Rakyat (BPR) Batang Palangki. https://doi.org/10.31219/osf.io/wupyh

Pongoh, G. S. Y., Areros, W. A., \& Mangindaan, J. V. (2019). Analisis Komparasi Kinerja Keuangan pada PT. Bank Negara Indonesia (Persero) Tbk dan PT. Panin Bank Periode 2014-2018. Jurnal Administrasi Bisnis, 9(2), 58. https://doi.org/10.35797/jab.9.2.2019.25113.58-69

Purba, H. Y. (n.d.). PERBANKAN ( Studi pada Bank-bank Milik Pemerintah yang Go Public di BEI ). 29(1), 86-94.

Rabuisa, W. F., Runtu, T., \& Wokas, H. R. N. (2018). Analisis Laporan Keuangan Dalam Menilai Kinerja Keuangan Perusahaan Pada Bank Perkreditan Rakyat (Bpr) Dana Raya Manado. Going Concern: Jurnal Riset Akuntansi, 13(02), 325-333. https://doi.org/10.32400/gc.13.02.19518.2018

Rahmayeli, D. S., \& Marlius, D. (2017). Analisis Kinerja Keuangan Pada PT. Bank Perkreditan Rakyat (BPR) Batang Kapas Pesisir Selatan. https://doi.org/10.31227/osf.io/sz5db

Risnawati, D. (2013). MENGETAHUI TINGKAT KESEHATAN BANK ( Studi Kasus PT . BNI ( Persero ), Tbk ). 7(4382), 24-29.

Sari, Y. P., \& Marlius, D. (2019). Analisis Rasio Profitabilitas Pada PT. Bank Negara Indonesia Syariah. https://doi.org/10.31219/osf.io/94bwq

Setiyono, W. P., \& Aini, M. N. (2016). Analisis Kinerja Keuangan Perbankan Dengan Menggunakan Metode Camel (Studi Kasus Pada Pt. Bpr Buduran Delta Purnama). JBMP (Jurnal Bisnis, Manajemen Dan Perbankan), 1(2), 175. https://doi.org/10.21070/jbmp.v1i2.271

Sipahelut, R. C., Murni, S., Rate, P. Van, Manajemen, J., Sam, U., \& Manado, R. (2018). Analisis Kinerja Keuangan Perusahaan (Studi Kasus Pada Perusahaan Sub Sektor Otomotif Dan Komponen Yang Terdaftar Di Bei Periode 20142016). Jurnal EMBA: Jurnal Riset Ekonomi, Manajemen, Bisnis Dan Akuntansi, 5(3), 4425-4434. https://doi.org/10.35794/emba.v5i3.18641 
Spica, L., \& Herdinigtyas, W. (2005). Analisis Rasio Camel Terhadap Prediksi Kondisi Bermasalah Pada Lembaga Perbankan Perioda 2000-2002. Jurnal Akuntansi Dan Keuangan, 7(2), 131-147. https://doi.org/10.9744/jak.7.2.pp.131-147

Syamsuddin, L. (2011). Manajemen Keuangan Perusahaan: Konsep Aplikasi dalam: Perencanaan, Pengawasan, dan Pengembaian Keputusan. Jurnal Administrasih Bisnis.

Taswan. (2010). Manajemen Perbankan: Konsep, Teknik, dan Aplikasi. In Yogyakarta: UPP STIM YKPN Yogyakarta.

Tri, C. septian. (2017). Simki-Economic Vol. 01 No. 08 Tahun 2017 ISSN : BBBBBBBB. Simki-Economic, 01(08), 14-16.

Walandouw, S., Sabijono, H., \& Tanor, M. (2015). Analisis Laporan Keuangan Dalam Mengukur Kinerja Keuangan Pada Pt. Bank Artha Graha Internasional, Tbk. Jurnal Riset Ekonomi, Manajemen, Bisnis Dan Akuntansi, 3(3), 639-649. https://doi.org/10.35794/emba.v3i3.9535

Yolanda, R., \& Kesuma, F. (2014). Analisis Laporan Keuangan Sebagai Dasar Dalam Penilaian Kinerja Keuangan Pt. Budi Satria Wahana Motor. JURNAL Akuntansi \& Keuangan, 5(1), 93-121. 